\title{
The Effect af Internet on English Learners' Learning Behavior
}

\author{
Syawal \\ awal.umpar@gmail.com \\ Patahuddin \\ elbazthakim@gmail.com \\ Nasrullah \\ nasrullahumpar@gmail.com \\ English Education Department, \\ Muhammadiyah University of Parepare, Indonesia
}

\begin{abstract}
Nowadays internet becomes the most popular information's source that people use to find information needed. However, it is very crucial that it serves advantages and disadvantages as well. In this study, the researcher focused on verifying internet disadvantages regarding to its negative effect on leraners' behaviour. This study was conducted at the Department of English Education, Faculty of Teachers Training and Education, Muhammadiyah University of Parepare utilizing questionnaire, involving the second and fourth semester Learners as the population. The samples were determined based on simple random sampling in which every individual in the population had an equal chance to be chosen as a sample. Findings indicated that most of the learners less creativity, internet addict, violation and plagiarism. Most of the Learners revealed that they prefer to copy data from internet than paste it to fulfill their assignment without editing. However, internet also becomes their alternative learning source better than other learning media. On the contrary, they thought library is not effective to overcome their obstacles in learning. Lack of idea, attention and brainstorming are considered as some of the causes. Role of lecturer and the used of plagiarism checker software are recommended, as well as the use of citation and reference software.
\end{abstract}

Keywords: Internet effect, learners' behavior, and reference software.

\section{INTRODUCTION}

The Internet can be interpreted as a large worldwide computers network that connects computer users from one country to another throughout the world, where in it there is a variety of information ranging from static to dynamic and interactive. The Internet has been used extensively almost in all aspects of human life. In general, the Internet serves as a liaison for people around the world through social networking that aims to share ideas, acquire new friends, sending electronic messages, exchange data, and others. In addition, the internet also provides benefits for businessmen, politicians and academics as well as learners. In terms of education, the Internet is considered as the easiest tool for obtaining information, literature or references which related to education.

Ideally, Internet used to gain information positively in everyday life such as for teaching materials and for entertainment without any negative sites. Negative sites should be 
blocked so that the learners are not so curious about the site. In terms of its use, the internet is quite influential on learners in this modern era. Internet in the form of news search tools, communications, etc. are very influential for modern society both in terms of benefits and impact. But be aware if the internet has become an opiate, it would be a negative impact as well.

Learners' learning behavior by accessing the internet can be head for negative effect which will impact on learners' creativity in completing their lectures. Similarly, the threat of Internet addiction is assumed can result in the lack of social interaction and learners' health. But the most worrying thing is the act of copy paste or in other words plagiarism. This habit, of course, is very detrimental to people who have intellectual property that is easily plagiarized and claimed by the learners a result of their work. Cosidering above reason, the researchers are intended to do research entittled "The effect of internet on learners' learning behavior". It is aimed to see how the learners behavior in acessing internet, how the learners' behavior using internet in fulfill their assignment and how learners' perspective of internet as learning media.

\section{REVIEW OF RELATED LITERATURE}

Internet has been used widely in all aspect of human's life. It is mainly used to connect people all around the world through social networking in purpose for sharing idea, getting fellows, mailing, data exchange, etc. Moreover, it is also become an opportunity in business industry, education, politics, etc. In academic purpose, it is assumed as an easiest way in obtaining the relevant information, literature, or references. Ito et al., in (Grace, Raghavendra, \& Connell, 2014) claim that "the use of internet technology for social networking is a pervading feature of youth culture today, with social and recreational online media used as much and as often as possible."

Intenet has been used worldwide and changed the pattern of life. A study by Ani (2010) reveals that the internet has become the most popularly used in academic environments by both academic staff and learners. In addition, (Akporido, 2005) state that the internet is a global super-highway through which decisions are now being made more quickly than ever before and it has had powerful and pervasive effects on every part of our lives including business, education, health, transport, communications and industry among others. On the contrary, (Vakkari, 2012) report that the internet is commonly seen as a threat to public library services. It provides a huge amount of information and effective tools for searching needed information. It is expected that the members of the audience compare information resources, services and tools provided by both suppliers and decide which activities best suit their needs. Another perspective coming from Zhou et al., 2014 who conclude that one of potential reasons for this negative effect on quality of life is the imbalanced allocation of time between Internet use and other regular leisure activities. Lastly, (Grace et al., 2014) reported that several studies found negative effects on mental health and suggested that in addition to education about the dangers of using the internet, young people should also receive education targeting more basic communication abilities such as social skills and other factors not specific to internet use and this might may buffer against the potential negative aspects of internet use.

Negative effect of internet is a process of engaging in improper activity to do something unworthy because of negative anxiety. Moreover, Martin in (Gencer \& Koc, 2012) report that excessive or unregulated usage has been associated with a condition of Internet- 
related disturbances calls "Internet abuse" referring to the "patterns of using the Internet that result in disturbances in a person's life but does not imply a specific disease process or addictive behavior". In addition, (Sandford, Parish, \& Sandford, 2007) Internet misuse is evolving sociologically as well as technologically. The potential gains from misusing networks are now being exploited by organized crime, marking a change in the scale and motivation of major network misuse. Regarding to that internet effect could be the misuse of internet for positive purpose becomes negative purpose. For example internet should be using for finding knowledge or literature but in fact it is used to copy and paste someone intellectual properties. In truth, positive or negative effect of internet defends on its users. It has been explain both positive and negative effect of it, so, it can be argued that if the user use it for positive purpose it will resulted on good effect conversely if the user use it for negative purpose it will effect on bad effect such pornography, violence, plagiarism and others academic violation.

\section{RESEARCH METHOD}

The aim of this study is to analyze the learners' behaviour on using internet as a media in completing their assignment given by their lecturer. It was focus on internet disadvantages regarding to its abuse toward the Learners' assignment. The method used in this research was qualitative study utilizing questionnaire. It was used to gain information regarding to Learners' behavior in using internet.

According to (Sugiyono, 2014) population is the area of generalization which consist of object/subject which has specific quality and characteristic that has been settled by the researcher to be studied and to be concluded. So, the population of this research was the second and fourth semester Learners at Department of English Education, Faculty of Teachers Training and Education, Muhammadiyah University of Parepare as his research population. Moreover, (Sugiyono, 2014) also define sample as part of number of quantity and characteristic belongs to population. That is why in determining research sample every individual in the population had an equal chance to be chosen as a sample. In choosing his sample, the researcher chose them randomly resulting on 43 Learners chosen as sample of the research.

In this research, data was collected through questionnaire in which it was divided into two sections namely biographical information and likert-scale. Biographical information involves current information of each Learners such us; sex of respondents, internet experience, access time, reasons for using internet, frequency and characteristics. Moreover, 10 questions were arranged as likert-scale in where each student should answer the question by giving score 5 to 1 referring to their agreement toward the question given.

\section{FINDINGS}

The results of the research regarding to Biographical information which involves gender of learners, internet experience, access time, reasons for using internet, frequency and characteristics can be seen in the following.

Table 1 revealed that more female $(80.26 \%)$ use internet than male $(19.74 \%)$ in this research. This research finding is possibly as a result of the greater number of female university learners than male. This particular findings equals to what (Akporido, 2005) 
Table 1 the percentage of learners' biographical information in using internet

\begin{tabular}{|c|c|c|c|c|c|}
\hline NO. & \multicolumn{2}{|c|}{ Biographical Information } & Frequency & Percentage & Total $(\%)$ \\
\hline \multirow{2}{*}{1} & \multirow{2}{*}{ Gender } & Male & 15 & 19,73 & \multirow{2}{*}{100} \\
\hline & & Female & 61 & 80,26 & \\
\hline \multirow{4}{*}{2} & \multirow{4}{*}{$\begin{array}{l}\text { Internet } \\
\text { Experience }\end{array}$} & Above 5 years & 64 & 84,21 & \multirow{4}{*}{100} \\
\hline & & $3-4$ years & 8 & 10,52 & \\
\hline & & $1-2$ years & 2 & 2,63 & \\
\hline & & Under 1 year & 2 & 2,63 & \\
\hline \multirow{3}{*}{3} & \multirow{3}{*}{ Access time } & Above 1 hour & 50 & 65,78 & \multirow{3}{*}{100} \\
\hline & & $30-60$ minutes & 16 & 21,05 & \\
\hline & & 01- 30 Minutes & 10 & 13,15 & \\
\hline \multirow{5}{*}{4} & \multirow{5}{*}{$\begin{array}{l}\text { Reasons for } \\
\text { using internet }\end{array}$} & Sending e-mail & 11 & 14,47 & \multirow{5}{*}{100} \\
\hline & & $\begin{array}{l}\text { Learning Management } \\
\text { System Ex. Edmodo }\end{array}$ & 17 & 22,36 & \\
\hline & & Social Network & 25 & 32,89 & \\
\hline & & $\begin{array}{ll}\text { Reading } & \text { for } \\
\text { assignment } & \end{array}$ & 19 & 25 & \\
\hline & & Others & 4 & 5,26 & \\
\hline \multirow{3}{*}{5} & \multirow{3}{*}{ Frequency } & Daily & 62 & 81,57 & \multirow{3}{*}{100} \\
\hline & & Weekly & 12 & 15,78 & \\
\hline & & Monthly & 2 & 2,63 & \\
\hline
\end{tabular}

discovered in his research. Moreover, a question regarding to Learners' experience in using internet revealed that $84.21 \%$ Learners has been using internet above 5 years, while $10.52 \%$ Learners has been using internet between $3-4$ years. The rest $4 \%$ Learners use it between 1-2 years and under a year. It proves that internet has been used by most of the Learners since they were in Junior high school. Another finding of this research is duration time of Learners in accessing internet was $65.78 \%$ accessed internet above 1 hour, $21.05 \%$ Learners accessed it between 30-60 minutes and the rest $13.15 \%$ Learners accessed it between 01-30 minutes. This findings indicate that more learners fulfill their leisure time to access internet just like (Zhou et al., 2014) findings in their research where Internet use is one of very common leisure activities in Chinese urban citizens; and age, gender, income level, and education level are the key important factors that affect Internet access.

In addition, most popular reason for using internet is to access social network (32.89\%). Their reason regarding to this matter is to keep in touch with their relatives, friends and others. But surprisingly, learning management system which is used by some lecturers in this particular research not becomes learners' priority in using internet $(22.36 \%)$. Moreover, only 25\% use internet for reading assignment purpose, 14.47 learners use internet for sending e-mail and $4 \%$ learners use it for other reason. This data reveals that academic reason not become top priority of the learners in using internet. The question about the learners' frequency in using internet show that most learners using internet 
daily (81.57\%), $12 \%$ learners use it weekly and only $2 \%$ learners use it monthly. This indicates that the learners don't have obstacle in using internet which is proved by their daily frequency in accessing internet.

In determining the learners' responses of internet effect on learning behaviour regarding to fulfill the assignment, the researcher used 5- point scale in which "5" categorized very often, and " 1 " is categorized very seldom. To simplify this research, the data is converted into percentage and researcher assumes that score over " 3 " is categorized "often" and score under 3 " 3 " is categorized "seldom" while " 3 " is categorized "neutral" (table 2). By the data in table 2, it is revealed that $63.15 \%$ learners finished their assignment by taking data through internet directly, $34.21 \%$ neutral and $2.63 \%$ seldom. Regarding to the use of internet as a media to solve learning obstacle, assignment, and looking for the latest lecturing information, $81.57 \%$ learners agreed that they are often gain it through internet. It is also indicated that $53.94 \%$ learners agreed to spend their leisure by browsing in internet. The question about learners' choice between surfing in internet than doing group assignment show that $47.36 \%$ prefer surfing in internet.

As shown in table 2, it is found that $50 \%$ learners often doing copy and paste to fulfill their lecturing assignment. This data was almost similar to the interpretation of question about learners' behavior regarding to editing process of the data gain from internet where $42.10 \%$ state that they seldom edit it. Regarding to commercialization of article or book downloaded from internet $18.42 \%$ learners do it. Meanwhile, $25 \%$ learners state that they had already known about hacking in internet. Lastly, $72.36 \%$ learners assume that internet is the most complete learning media, this assumption was in line to the last question that conventional library was not effective to overcome their obstacle in lecturing assignment $(38.15 \%)$.

Table 2 The percentage of learners' responses of internet misusage regarding to their assignment

\begin{tabular}{llcccccc}
\hline \multirow{2}{*}{ No } & \multicolumn{1}{c}{ Statement } & $\begin{array}{c}\text { Very } \\
\text { Often }\end{array}$ & Often & $\begin{array}{c}\text { Someti } \\
\text { mes }\end{array}$ & $\begin{array}{c}\text { Seld } \\
\text { om }\end{array}$ & Never & $\begin{array}{c}\text { Total } \\
(\%)\end{array}$ \\
\cline { 2 - 6 } & $\%$ & $\%$ & $\%$ & $\%$ & $\%$ & 100 \\
\hline $\begin{array}{l}\text { I finished my assignment } \\
\text { by gaining data from } \\
\text { internet directly. }\end{array}$ & 26,32 & 36,84 & 34,21 & 2,63 & 0 & 100 \\
\hline $\begin{array}{l}\text { I use internet to overcome } \\
\text { my learning obstacle, } \\
\text { assignment and looking } \\
\text { for latest information. }\end{array}$ & 35,53 & 46,05 & 17,11 & 1,31 & 0 & 100 \\
\hline $\begin{array}{l}\text { I prefer browsing on } \\
\text { internet in my leisure. }\end{array}$ & 22,37 & 31,57 & 39,47 & 6,57 & 0 & 100 \\
\hline $\begin{array}{l}\text { I prefer browsing on } \\
\text { internet than doing my } \\
\text { group assignment. }\end{array}$ & 19,74 & 27,63 & 39,47 & 5,26 & 7,89 & 100 \\
\hline
\end{tabular}




\begin{tabular}{|c|c|c|c|c|c|c|c|}
\hline 5 & $\begin{array}{l}\text { I like to copy and paste } \\
\text { regarding to fulfill my } \\
\text { assignment. }\end{array}$ & 15,79 & 34,21 & 32,89 & 14,4 & 2,63 & 100 \\
\hline 6 & $\begin{array}{l}\text { I often do editing process } \\
\text { to the data gained from } \\
\text { internet. }\end{array}$ & 6,579 & 15,78 & 35,53 & 21,0 & 21,1 & 100 \\
\hline 7 & $\begin{array}{l}\text { I often commercialize } \\
\text { books or article gained } \\
\text { from internet. }\end{array}$ & 6,579 & 11,84 & 35,53 & 23,6 & 22,4 & 100 \\
\hline 8 & $\begin{array}{l}\text { I often gained data from } \\
\text { internet helping by hacker } \\
\text { or learn from them. }\end{array}$ & 6,579 & 18,42 & 32,89 & 11,8 & 30,3 & 100 \\
\hline 9 & $\begin{array}{l}\text { I often assume that } \\
\text { internet is the most } \\
\text { complete learning } \\
\text { resource. }\end{array}$ & 30,26 & 42,10 & 23,68 & 3,94 & 0 & 100 \\
\hline 10 & $\begin{array}{l}\text { I often assume that } \\
\text { conventional library is } \\
\text { not effective to solve my } \\
\text { assignment. }\end{array}$ & 7,895 & 30,26 & 38,16 & 10,5 & 13,2 & 100 \\
\hline
\end{tabular}

Based on the data presented in table 1 and table 2, it can be interpreted that internet as a learning media was not fully optimized even it is already lead to internet misuse. In other words, it leads to the decreased of Learners' creativity. (Kirschner \& Karpinski, 2010), (Kuss \& Griffiths, 2011) and (Alhazmi \& Abdul Rahman, 2013) agreed that internet (social networking sites) gives a negative effect on Learners grade points average. Although some other researcher found that the use of internet as learning media able to influence Learners learning motivation as well as their creativity (Rhosyied \& Otok, 2008) but in terms of Learners' assignment, the researcher believes that it can attract the Learners to search data from internet even it just a very easiest assignment. Learners' behavior on taking data directly from internet to finish their assignment should become educators attention in order to avoid more serious harmful in the future. Educators may adopt idea coming from Hinman in (Scanlan, 2006) who offers insightful solutions to dissuade many Learners from cheating.

Learners behavior in internet usage also may effect on the decrease in real life social community participation as well as relationship problems, each of which may be indicative of potential addiction (Kuss \& Griffiths, 2011). (Zhou et al., 2014) in his research reported that Internet users reported less engagement in physical activities such as playing Sports/physical exercise for health than non-Internet users did. Along with these previous research findings, this research discovered more serious negative effect as the data show that Learners prefer to fulfill their leisure by browsing in internet. In addition, it is also harmful that Learners even dare to omit their group assignment because of their internet activities. Having behavior such like internet addiction will also effect on less time in reading some information as well as less time for learning. 
The Learners' activity regarding to their assignment also lead to copy and paste activities without any editing process or paraphrasing. It cannot be argued because the easiest way of accessing internet will effect on plagiarism act as what Spinello in (Scanlan, 2006) address about the issues of copyright and intellectual property on the Internet. Equally, (Ukpebor \& Ogbebor, 2013) argued that the Internet now makes it easy to find thousands of relevant sources in seconds, and in the space of a few minutes plagiarists can find, copy, and paste together an entire term paper or essay because much of the material online is produced by other Learners, it is often difficult or impossible for educators to identify plagiarism based on expectations of learners-level work. (Bijle \& Patil, 2014) report that plagiarism is considered as a deceit or an offence which does not have a legal implication per se. This research deals with (Ukpebor \& Ogbebor, 2013) terminology "culture of academic dishonesty." Copying and pasting should become intention to be reduce even to be banned in academic purposed. This action is very fidgety by all writer, researcher and even publisher.

The glowing of internet negative effect such as commercialization of book or article without copy rights as well as black hacker is assumed as cybercrime. In addition, getting aid from hacker to gained data also leads to learners' negative behavior. It is ridiculous. Even if the book or article was download from any paid websites. This finding is meaningful on how the learners try to do such business activity regarding to their assignment and do it on purpose to decrease their economical difficulty. Yet, they need to aware that it is a kind of criminal activity.

Some learners assume that internet is the most complete learning media as well as assume that conventional library was not effective to overcome their obstacle in lecturing assignment. Nevertheless, they have to understand that there should be any mechanism to be followed to avoid violation in internet usage. Most cases of plagiarism can be avoided, however, by citing sources (Ukpebor \& Ogbebor, 2013). The usage of internet as learning media should be significance as media for looking information as well as deepen their understanding regarding to their assignments. As consideration that what author or researcher already stated in their article doesn't guarantee that it has the same situation and condition with our assignment condition. Equally, the usage of conventional library, although it is considered ineffective but it's ineffective perhaps caused by lack of attention and less discussion on each cases. Further research will be more explores this matter of case.

\section{CONCLUSION AND SUGGESTION}

Data analysis leads the researcher comes to conclusion regarding to this research. Internet effect regarding to learners' learning behaviour involves four main problem, they are: less creativity of the Learners, violence, plagiarism and commercialization without copy rights. Laziness and less creativity of the learners are considered as the core of internet abuse regarding to their assignment. Moreover, omitting the university rule as well as participation in real life socialization because of learners' addiction on internet also considered as an internet negative effect. This may lead to amoral activity by telling lie to their lecturer, friends or even their parents. Simply, they may have reason that they spent a lot of their time accessing internet for academic purpose but on the contrary they just surfing, browsing, online games or event access any unuseful social networking. Thinking hard and reading for purpose of getting information might contribute to copy and paste as their shortcut to fulfill their assignment. It's a simple and the easiest way 
resolving their obstacle in completing their assignment. Lastly, the easiest way provides by internet also leads to commercialization without copy rights. Of course many reasons become their background in doing so such as low economical background and part time job.

Considering the effect of internet regarding to its negative effect on Lerners' learning behaviour on doing assignment, some suggestion are proposed: firstly, role of lecturer is considered as an alternative way to resolve this case. By providing good lecturing approach, such as accept only reference coming from scholarly journal. Because according to the previous report by the plagiarism-detection tool TurnItIn in (Ukpebor \& Ogbebor, 2013) confirm that most Learners copying data from Wikipedia and Yahoo answers as Top sources. In line with this, the uses of plagiarism checker software are recommended for lecturer as their defense to ban such of internet misuse. At last, it is also suggested to use citation and reference software for ensuring the originality of paper submitted by the Learners.

\section{REFERENCES}

Akporido, C. E. 2005. Internet use in a Nigerian suburban setting. The Electronic Library, 23(3), 302-310. https://doi.org/10.1108/02640470510603705

Alhazmi, A. K. \& Abdul Rahman, A. 2013. Facebook in Higher Education: Students' Use and Perceptions. Advances in Information Sciences \& Service Sciences, 5(15), 32-41.

Ani, O. E. 2010. Internet access and use A study of undergraduate students in three Nigerian universities, 28(4), 555-567. https://doi.org/10.1108/02640471011065373

Bijle, M. N. A., \& Patil, S. 2014. Plagiarism: An Academic Offence. Journal of International Oral Health: JIOH, 6(2), i-i. Retrieved from http://www.ncbi.nlm.nih.gov/pmc/articles/PMC4037758/

Gencer, S. L., \& Koc, M. 2012. Internet abuse among teenagers and its relations to internet usage patterns and demographics. Educational Technology and Society, $15(2), 25-36$.

Grace, E., Raghavendra, P., \& Connell, T. 2014. Learning to use the Internet and online social media: What is the effectiveness of home-based intervention for youth with complex communication needs? https://doi.org/10.1177/0265659013518565

Kirschner, P. A., \& Karpinski, A. C. 2010. Facebook?? and academic performance. Computers in Human Behavior, 26(6), 1237-1245. https://doi.org/10.1016/j.chb.2010.03.024

Kuss, D. J., \& Griffiths, M. D. 2011. Online social networking and addiction-A review of the psychological literature. International Journal of Environmental Research and Public Health, 8(9), 3528-3552. https://doi.org/10.3390/ijerph8093528 
Nunan, David \& Bailey, K. M. 2009. Exploring Second Language Classroom Research: A Comprehensive Guide. Australia: Heinle, Cengage Learning.

Patahuddin; Syawal; Bin-tahir, S. Z. 2017. Investigating Indonesian EFL Learners ' Learning and Acquiring English Vocabulary, 7(4), 128-137. https://doi.org/10.5539/ijel.v7n4p128

Rhosyied, A., \& Otok, B. W. 2008. Analisa pengaruh penggunaan internet sebagai media belajar, motivasi belajar dan kreativitas terhadap prestasi belajar siswa dengan menggunakan, (2007), 1-9.

Sandford, P., Parish, D. J., \& Sandford, J. M. 2007. Understanding Increasing Traffic Levels for Internet Abuse Detection, 63-77. https://doi.org/10.1057/palgrave.sj.8350051

Scanlan, M. (2006). Book Review: The Impact of the Internet on Our Moral Lives. New $\begin{array}{llll}\text { Media \& Society, } & \text { 8(2005), }\end{array}$ https://doi.org/10.1177/146144480600800313

Sugiyono, P. D. 2014. Metode Penelitian Kuantitatif Kualitatif dan $R \& D$ (21st ed.). Indonesia: ALFABETA. Retrieved from www.cvalfabeta.com

Uddin, M. N. (2003). Internet use by university academics: a bipartite study of information and communication needs. Online Information Review, 27(4), 225237. https://doi.org/10.1108/14684520310489014

Ukpebor, C. O., \& Ogbebor, A. 2013. Internet and Plagiarism: Awareness, Attitude and Perception of Students of Secondary Schools. Journal of Library \& Information Science, 3(2), 254-267. https://doi.org/10.1017/CBO9781107415324.004

Vakkari, P. 2012. Internet use increases the odds of using the public library. Journal of Documentation, 68, 618-638. https://doi.org/10.1108/00220411211256003

Zhou, R., Fong, P. S. W., \& Tan, P. (2014). Internet use and its impact on engagement in leisure activities in china. PLoS ONE, 9(2). https://doi.org/10.1371/journal.pone.0089598 